\title{
Evans syndrome in child with sudden blindness
}

Muhammad Fadhli Ab Hamid ${ }^{1}$, Choo May May ${ }^{1,2}$, Nurliza Khaliddin ${ }^{1,2}$ Norlina Mohd Ramli $^{1,2}$

${ }^{1}$ Department of Ophthalmology, Faculty of Medicine, University of Malaya, Kuala Lumpur, Malaysia; ${ }^{2}$ University Malaya Eye Research Centre, University Malaya Medical Centre, Kuala Lumpur, Malaysia

\section{Abstract}

A 3-year-old girl presented with sudden onset of bilateral vision loss on waking up from sleep. There had been no associated eye pain, eye redness, fever or history of trauma in the days leading up to the presentation. She had been diagnosed with Evans syndrome at the age of 18 months and started on a regular dose of oral prednisolone under regular follow-up at the paediatric clinic. Upon presentation, her visual acuity was light perception bilaterally, with relative afferent pupillary defect in the right eye and sluggish pupils bilaterally. Bilateral fundus examination showed normal macula and pink optic discs without papilloedema. Other systemic examinations were unremarkable. The provisional diagnosis was severe bilateral retrobulbar optic neuritis, prompting further investigations to rule out infectious or vasculitic causes. Extensive investigations were carried out during admission including infective screenings of blood and urine, all of which were negative. A contrasted magnetic resonance image of the brain showed both orbital segments were swollen and appeared hyperintense, with involvement of the intracanalicular and intracranial segments, suggesting an inflammatory or demyelinating aetiology. A visual evoked potential test to rule out demyelination disease was also normal. As intravenous methylprednisolone treatment appeared to have a slow effect, the treatment was switched to intravenous gammaglobulin. The patient responded well to treatment, and her latest visual acuity assessment 1 month after presentation showed bilateral vision of 6/24. This is the first-ever Evans syndrome patient to be reported worldwide with bilateral optic nerve sterile inflammation.

Correspondence: Dr. Muhammad Fadhli Ab Hamid, MBBS (UM), Department of Ophthalmology, Faculty of Medicine, University of Malaya, 50603 Kuala Lumpur, Malaysia.

E-mail: messentry7@yahoo.com 
Keywords: Evans syndrome, gammaglobulin, optic neuritis

\section{Sindrom Evans pada kanak-kanak dengan kebutaan secara tiba-tiba}

\section{Abstrak}

Seorang gadis berusia 3 tahun mengalami kemerosotan penglihatan pada kedua belah mata secara tiba-tiba ketika bangun dari tidur. Tidak ada kaitan dengan sakit mata, kemerahan mata, demam atau riwayat trauma pada hari-hari sebelum konsultasi. Dia telah didiagnosis dengan sindrom Evans pada usia 18 bulan dan memulakan dos prednisolon oral dengan kerap di klinik pediatrik. Semasa kehadiran beliau diklinik mata, ketajaman penglihatannya adalah persepsi cahaya secara pada kedua mata, dengan kecacatan pupil relatif relatif di mata kanan dan pupil tidak bertindakbalas dengan baik pada kedua-dua mata. Pemeriksaan fundus kedua mata menunjukkan makula yang normal dan warna cakera optik normal tanpa papilloedema. Pemeriksaan sistemik lain adalah normal. Diagnosis utama adalah neuritis optik retrobulbar kedua mata yang teruk, mendorong penyelidikan lebih lanjut untuk memastikan ianya disebabkan jangkitan atau vaskulitik. Siasatan menyeluruh dilakukan termasuklah pemeriksaan darah dan air kencing untuk jangkitan, dan semuanya negatif. Gambar resonans magnetik (MRI) otak berkontras menunjukkan kedua-dua segmen orbit membengkak dan terdapat tanda hiperintens, iaitu menglibatkan segmen intrakanalikular dan intrakranial, yang menunjukkan etiologi inflamasi atau demilining. Ujian potensi yang dihasilkan secara visual untuk menyingkirkan kemungkinan penyakit demyelinasi juga normal. Oleh kerana rawatan metilprednisolon intravena nampaknya memberi kesan yang perlahan, rawatan tersebut ditukar kepada gammaglobulin intravena. Pesakit memberi respons yang baik terhadap rawatan, dan penilaian ketajaman visual terbarunya 1 bulan selepas persembahan menunjukkan penglihatan kedua belah mata ialah 6/24. Ini adalah pesakit sindrom Evans pertama yang dilaporkan di seluruh dunia dengan keradangan steril saraf optik kedua mata.

Kata kunci: gammaglobulin, neuritis optik, sindrom Evans 


\section{Case report}

A 3-year-old girl with underlying Evans syndrome (ES) presented with sudden onset, bilateral visual loss upon waking up from sleep. There had been no associated eye pain, eye redness, fever or history of trauma in the days leading up to the presentation. She had been diagnosed with ES at the age of 18 months, presenting with recurrent infections, autoimmune haemolytic anaemia, and thrombocytopenia. After diagnosis, the patient was on a maintenance dose of prednisolone syrup 2.5 mg daily, which had been successfully tapered off after six months.

Upon ophthalmological assessment, her visual acuity was light perception bilaterally. There was relative afferent pupillary defect (RAPD) in the right eye. A sluggish pupillary light reaction on direct pupillary light reflex was observed bilaterally. A fundus examination turned out normal in both eyes, with absence of papilloedema. Other systemic examinations were unremarkable.

The provisional diagnosis was bilateral retrobulbar optic neuritis. Extensive examinations and investigations were carried out upon admission including vasculitis and infective screening of blood and urine, all of which were negative. Serum aquaporin 4 and anti-myelin oligodendrocyte glycoprotein (MOG) were negative, ruling out neuromyelitis optica spectrum disorder. Magnetic resonance imaging (MRI) with contrast of the brain showed swelling of the orbital portion of both optic nerves, which appeared to be hyperintense on the T2-weighted image, with involvement of the intracanalicular and intracranial segments, suggesting an inflammatory or demyelinating aetiology (Fig. 1). Analysis of a cerebrospinal fluid sample obtained

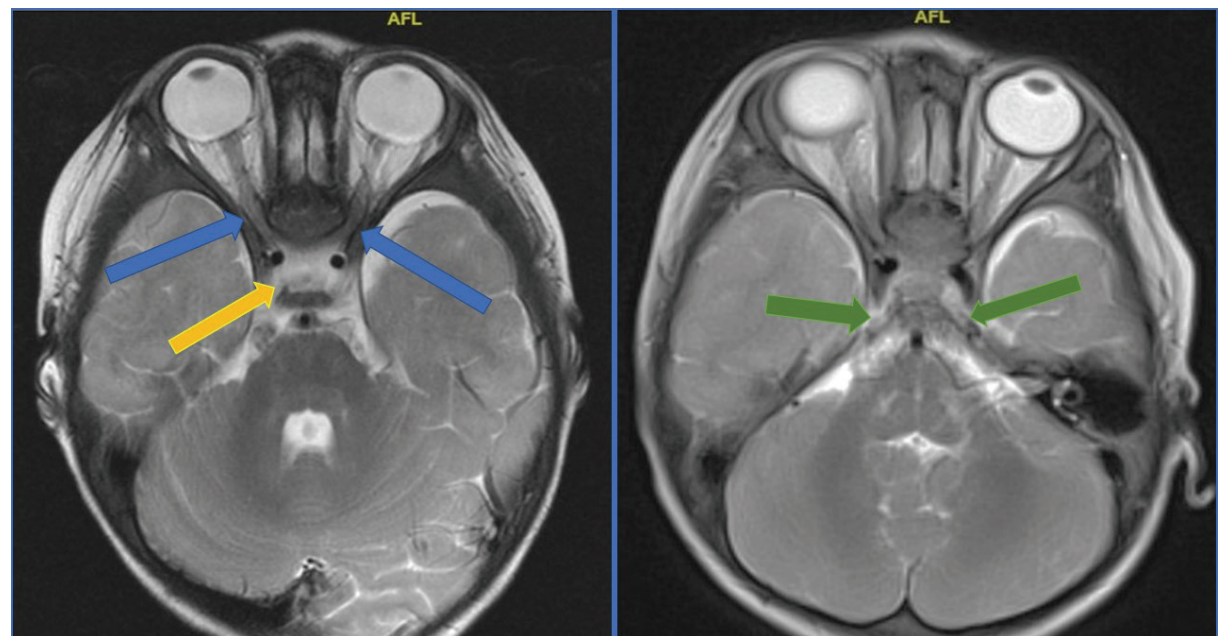

Fig. 1. A contrasted brain MRI at orbital cut (T2-weighted axial view) showing the bilateral optic nerve (blue arrow), chiasm, (yellow arrow) and optic tract are oedematous and swollen. Both optic tracts are hyperintense (green arrow). 
from the lumbar puncture was normal. Interestingly, a visual evoked potential (VEP) test showed no obvious waveforms to suggest defects in the visual pathways.

Intravenous methylprednisolone $370 \mathrm{mg}$ daily $(30 \mathrm{mg} / \mathrm{kg}$ ) was commenced on the day of admission and extended until day 7 . The response to treatment was monitored using Optokinetic Drum, Teller Acuity Chart, and RAPD on a daily basis. By day 7 of treatment, there was only subtle evidence of ophthalmologic clinical improvement. She was then started on intravenous (IV) infusion of immunoglobulin $12.5 \mathrm{~g}$ daily $(\mathrm{g} / \mathrm{kg} /$ day) for 2 days, in view of the slow and poor response.

After she completed the immunoglobulin, her visual acuity improved to at least $6 / 60$ bilaterally. She was able to navigate her way around a room. The right-eye RAPD was still positive. Since she had shown good response to treatment, she was discharged home with a tapering dose of prednisolone syrup of $10 \mathrm{mg}$ daily for the first week, $5 \mathrm{mg}$ daily for the second week, and $2.5 \mathrm{mg}$ daily for the third week. During the last follow-up, 1 month after initial presentation, her visual acuity had improved to 6/24 bilaterally, and both optic discs still appeared to be normal. Her parent reported that she was able to walk around the house without bumping into objects and could point at objects correctly.

\section{Discussion}

ES is a combination of Coombs positive autoimmune haemolytic anaemia, immune thrombocytopenic purpura, and, less commonly, autoimmune neutropenia. It is a diagnosis of exclusion after all infections, malignancies, autoimmune diseases, recent vaccinations, drugs, or a family history of immune disorders have been ruled out. $^{1}$ The pathophysiology of ES is not clearly understood, but it is postulated to involve autoantibodies directed against a base protein of an Rh blood group, thus destroying red blood cells, and a separate group of autoantibodies directed against platelet GPIIb/IIla, thus destroying platelets. ${ }^{1,2}$ Interestingly, nearly $50 \%$ of cases of ES are associated with autoimmune conditions such as systemic lupus erythematous, lymphoproliferative disorders, and common variable immunodeficiency. Its chronic course is characterized by recurrent relapses and remissions. ${ }^{1-3}$

Ocular complications are rarely reported in patients with ES. There is one particular case that reported an association with atypical retinitis pigmentosa and central retinal artery occlusion. ${ }^{4}$ As both optic neuritis and ES share a common underlying autoimmune pathology, it could be postulated that dysregulation of autoimmune antibodies derived from peripheral or central nervous system-infiltrating plasma cells occurs. ${ }^{5}$ Another study on a long-term follow-up of children with ES found that the disease may be an initial expression of immunologic disease, such as systemic lupus erythematous, which is known to be associated with optic neuritis. ${ }^{6}$ The combination of ES and optic neuritis in this young patient is rare, but not inexplicable. To date, no randomized, controlled trial has been established as 
a standardized treatment for ES. However, immunoglobulin infusion is well known to be used in cases of severe relapse where there was refractory response towards high-dose corticosteroids. ${ }^{7}$ VEP has a sensitivity of $60-80 \%$ in acute optic neuritis cases. ${ }^{8}$ In cases of clinical optic neuritis with a normal VEP, as in this particular case, a multifocal VEP may offer higher accuracy. ${ }^{9}$

This is the first case of ES associated with severe bilateral optic neuritis in the available literature worldwide. Intravenous methylprednisolone remains the first-line treatment, and switching to immunoglobulin infusion should be considered in steroid non-responder cases.

\section{Acknowledgements}

The patient's parent provided informed consent for the use and publication of the clinical details and images contained in this case report.

\section{References}

1. Ghashghaei R, Popa CR, Shen J. Evans Syndrome. Am J Med. 2013;126(11):e7-8.

2. Michel M. Warm autoimmune haemolytic anemias and Evans syndrome in adults. Rev Med Intern. 2008;29:105-114.

3. Michel M, Chanet V, Dechartres A, et al. The spectrum of Evans syndrome in adults: new insight into the disease based on the analysis of 68 cases. Blood. 2009;114(15):3167-3172.

4. Ababneh LT, Mahmoud IH, Al-Rimawi H.S. A rare case of Evans syndrome associated with sudden loss of vision: A case report. Eur J Ophthalmol. 2020;30(2):NP1-NP11.

5. Simon OJ, Kuhlmann T, Bittner S, et al. Evans syndrome associated with sterile inflammation of the central nervous system: a case report. J Med Case Rep. 2013;7:262.

6. Rivalta B, Zama D, Pancaldi G, et al. Evans Syndrome in Childhood: Long Term Follow-Up and the Evolution in Primary Immunodeficiency or Rheumatological Disease. Front Pediatr. 2019;7:304

7. Norton A, Roberts I. Management of Evans syndrome. Br J Haematol. 2006;132:125-137.

8. Fredrikson JL, Petrera J. Serial visual evoked potentials in 90 untreated patients with acute optic neuritis. Surv Ophthalmol 1999;44(suppl 1):S54-S62.

9. Grover LK, Hood DC, Ghadiali Q, et al. A comparison of multifocal and conventional visual evoked potential techniques in patients with optic neuritis/multiple sclerosis. Doc Ophthalmol. 2008;117(2):121-128 